\title{
AN ANTIGLOBULIN TEST FOR THE DETECTION OF SURFACE ANTIGENS OF MOUSE SPERMATOZOA
}

\author{
R. P. ERICKSON* \\ Division of Experimental Biology, National Institute of Medical Research, \\ Mill Hill, London
}

(Received 20th Fuly 1971, accepted 12th August 1971)

Although a variety of methods have been used for measuring antibodies to spermatozoa, many have only been qualitative, for instance immunofluorescence. The most commonly used technique, sperm agglutination, would not measure non-precipitating antibodies. The more recently developed cytotoxic tests (Hamerlynck \& Rümke, 1968) also detect a limited spectrum of antibody types. Binding tests which measure antibody absorbed to a target cell have rarely been used in studies of sperm antigens. Noyes (1969) used a direct binding test for human anti-sperm antibodies which involved labelling a patient's sera with ${ }^{131} \mathrm{I}$. In the work described here, an isotopic antiglobulin technique (Harder \& McKhann, 1968; Bomford, Breitner, Mitchison, Negroni \& Raff, 1969; Sparks, Ting, Hammond \& Herberman, 1969) has been adapted for use with mouse spermatozoa. This is an indirect or 'sandwich' technique which utilizes ${ }^{125}$ I-rabbit-anti-mouse- $\gamma$-globulin to detect mouse anti-mouse-spermatozoa antibodies bound to spermatozoa. The one radioactive reagent can be used with many different mouse antisera and, thus, obviates the need to iodinate each separately, a requirement of the direct technique.

The mouse anti-mouse-spermatozoa antisera used in the development of the test were hyperimmune antisera prepared in random-bred $Q$ strain female mice using an 8-week course of thrice weekly injections of spermatozoa (Bell \& McLaren, 1970). Serum from mice immunized with whole spermatozoa (Group Sp) or the supernatant fraction of disrupted spermatozoa (Group Sup + Sup-A) were pooled and designated Pool S and T-34, respectively. A rabbit anti-mouse- $\gamma$-globulin was prepared by immunization of rabbits with the purified $\gamma$-globulin from non-immune CBA mice prepared by ammonium sulphate fractionation and DEAE cellulose ion-exchange chromatography (Fahey, 1967). The resultant rabbit anti-mouse- $\gamma$-globulin serum was carefully purified before labelling by an immunoadsorbent column. The easily purified mouse $\gamma$-globulin (IgG 2a) myeloma protein, MOPG 5563, was covalently linked to cyanogen-bromide-activated Sepharose (Axen, Porath \& Ernback, 1967). The rabbit anti-mouse- $\gamma$-globulin serum was passed over a column of the immunoadsorbent and non-bound protein removed by continued washing with borate buffer. The specific rabbit anti-mouse- $\gamma$-globulin was then eluted with $0.1 \mathrm{~m}$-acetic acid. The specificity of this reagent was tested by immunoelectro-

* Present address: Department of Pediatrics, University of California Medical Center, San Francisco, Cal. 94122, U.S.A. 
phoresis. A single arc (with three spurs) of reactivity in the $\gamma$ region was found when the purified antiserum was allowed to react with normal CBA sera subjected to electrophoresis. The three spurs on the arc of precipitation indicate that this heteroantiserum does not react only with the single class of IgG used in the purification. The antiglobulin was labelled with ${ }^{125} \mathrm{I}$ by the chloramine $\mathrm{T}$ method (Freeman, 1967). This was performed with $100 \mu \mathrm{Ci}$ carrier-free ${ }^{125} \mathrm{I}$ for $25 \mu \mathrm{g}$ purified antiglobulin in phosphate buffer, the iodinated protein was diluted in $10 \%$ normal rabbit sera in borate buffer after the iodination was terminated by the addition of the sodium metabisulphite. The final iodine: antiglobulin molar ratio was $1: 10$ while the specific activity ranged around $1 \mathrm{mCi}{ }^{125} \mathrm{I} / \mathrm{mg}$ protein. Autoradiography of immunoelectrophoretograms of the labelled antiglobulin demonstrated that its specificity had been maintained.

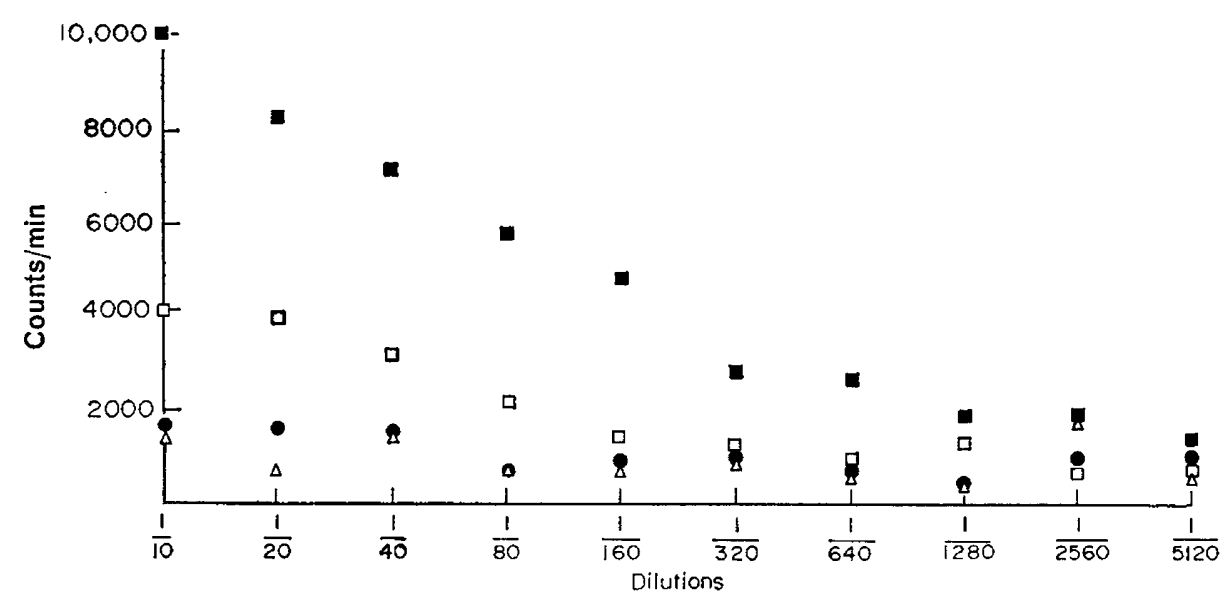

Text-FIG. 1. Absorption of normal $\gamma$-globulin (e, CBA; $\triangle, B A L B / c)$ and immune $\gamma$-globulin ( $\square$, pool $S$; $\square, T-34$ ) to CBA spermatozoa as determined using ${ }^{125}$ I-rabbitanti-mouse antiserum.

For the assay $5 \times 10^{5}$ to $10^{6}$ spermatozoa (prepared by screening from sliced vasa deferentia and epididymides in Oxoid C.F.T. diluent, $\mathrm{pH} 7.2$ with barbitone, $0.575 \mathrm{~g} / \mathrm{l} ; \mathrm{NaCl} 8.5 \mathrm{~g} / \mathrm{l} ; \mathrm{MgCl}_{2} 0.168 \mathrm{~g} / 1 ; \mathrm{CaCl}_{2} 0.028 \mathrm{~g} / \mathrm{l} ;$ and soluble barbitone, $0 \cdot 185 \mathrm{~g} / \mathrm{l}$ ) with $0 \cdot 1 \%$ bovine Fraction $\mathrm{V}$ (crude bovine serum albumin, BSA, Sigma) were incubated for $30 \mathrm{~min}$ at room temperature with $0.1 \mathrm{ml}$ of serum (normal or antiserum) in $12 \times 75 \mathrm{~mm}$ disposable (Kimble) or acid washed $6 \times 50 \mathrm{~mm}$ fermentation tubes. The spermatozoa were then washed three times with $1 \mathrm{ml}$ of the C.F.T.-B.S.A. medium using 5-min spins at $600 \mathrm{~g}$. The final pellets were transferred to fresh tubes using disposable Pasteur pipettes and $1 \mathrm{ml}$ of the C.F.T.-B.S.A. medium. After a fourth centrifugation and aspiration of the supernatant, 5 to $10 \lambda$ of the labelled rabbit antibody were added and the tubes were vibrated. After being incubated for $15 \mathrm{~min}$ at room temperature, the spermatozoa were washed eight times as before and the final pellets counted.

The absorption of immune and normal serum $\gamma$-globulin to CBA spermatozoa at various dilutions of the antisera provide a demonstration of the technique (Text-fig. 1). Both normal sera led to low levels of binding at low dilutions of the 
sera and the binding of radioactivity was not greatly decreased at high dilutions. Immune sera gave a much larger binding of $\gamma$-globulin at low dilutions ( $\mathrm{T}-34$ was the stronger antisera in this case) but this binding dropped off to the level of normal sera at high dilutions. The absorption ratio (AR) is calculated from the ratio of the quantity of $\gamma$-globulin bound with the immune sera (measured by ${ }^{125} \mathrm{I}$ counts) to the quantity bound by a normal serum at the same dilution (also assumed to be directly correlated with the ${ }^{125} \mathrm{I}$ counts). The AR is a single parameter measuring the degree of reaction. The normal serum should be from the same strain as the antiserum although there is little effect if it is not (Text-fig. 1). The relative strengths of several different antisera are found at different dilutions (Table 1). The antisera in this case do not seem to distinguish any alloantigens on mouse spermatozoa as they react equally

TABLE 1

ABSORPTION RATIOS FOR POOL S AND T-34 WTTH

CBA AND C3H SPERMATOZOA

\begin{tabular}{c|cc|cc}
\hline \multirow{2}{*}{$\begin{array}{c}\text { Reciprocal } \\
\text { dilution of serum }\end{array}$} & \multicolumn{2}{|c|}{ Pool $S$} & \multicolumn{2}{c}{ T-34 } \\
\cline { 2 - 5 } & $C 3 H$ & $C B A$ & $C 3 H$ & $C B A$ \\
\hline 50 & 4.9 & 2.5 & 9.0 & 5.8 \\
250 & 1.7 & 1.9 & 3.3 & 4.2 \\
1000 & 1.7 & 1.4 & 3.8 & 3.7 \\
2500 & 1.0 & 1.1 & 1.8 & 2.0 \\
10000 & 0.5 & 0.7 & 0.6 & 0.7 \\
\hline
\end{tabular}

strongly with several different strains of mice (Table 1). No reaction of the antisperm antisera with lymphocytes can be detected with the antiglobulin test; a weak reaction with red blood cells has not been studied further. Presumably, the major antigen these antisera detect is a histospecific antigen found in many strains of mice.

The test is reproducible and easily performed; fifty to seventy-five tubes/day are readily handled by one person. It was developed using the antisera from hyperimmunized mice provided by Dr Eric Bell, but has been useful in detecting alloantigens on mouse spermatozoa using antisera prepared with short schedules of immunization (Erickson, unpublished observations). The test, at present, is limited to detecting absorbed IgG antibodies. It might be more sensitive if it could detect IgM as well.

This work was done during the tenure of N.I.H. Special Fellowship IF03HD43252. I thank Dr N. A. Mitchison and the Division of Experimental Biology for their warm hospitality, Dr Eric Bell for his generous gift of antisera, Dr Peter Beverley for his useful discussions, and Miss Janet Cowan for her skilful technical assistance.

\section{REFERENGES}

Axzn, R, Porath, J. \& ERnback, S. (1967) Chemical coupling of peptides and proteins to polysaccharides by means of cyanogen halides. Nature, Lond. 214, 1302.

Bell, E. B. \& McLaren, A. (1970) Reduction of fertility in female mice iso-immunized with a subcellular sperm fraction. F. Reprod. Fert. 22, 345. 
Bomford, R., Breitner, J., Mitchison, N. A., Negroni, N. \& Raff, M. (1969) Detection of cell antigens by cytotoxicity, radio-uptake and other methods. In: Immunity and Tolerance in Oncogenesis, p. 135. Ed. L. Severi. IV Perugia Quadrennial Int. Conf. on Cancer, Italy.

FAHEY, J. F. (1967) Chromatographic separation of immunoglobulins. In: Methods in Immunology and Immunochemistry, p. 321. Eds. G. A. Williams and M. W. Chase. Academic Press, London.

Freeman, T. (1967) Trace labelling with radioiodine. In: Handbook of Experimental Immunology, p. 597. Ed. D. M. Weir. Blackwell Scientific Publications, Oxford.

Hamerlynck, J. \& RümKe, Ph. (1968) A test for the detection of cytotoxic antibodies to spermatozoa in man. F. Reprod. Fert. 17, 191.

Harder, F. H. \& McKhann, C. F. (1968) Demonstration of cellular antigens on sarcoma cells by an indirect ${ }^{125} \mathrm{I}$ labelled antibody technique. 7 . natn. Cancer Inst. 40, 231.

Noyes, R. W. (1969) Antibody binding of spermatozoa. Fert. Steril. 20, 43.

Sparks, F. G., Ting, G. G., Hammond, W. G. \& Herbermann, R. B. (1969) An isotopic antiglobulin technique for measuring antibodies to cell-surface antigens. F. Immun. 102, 842. 